\title{
ANALISIS KEBUTUHAN MEDIA AUDIO CERITA PENDIDIKAN KARAKTER UNTUK ANAK USIA DINI
}

\section{NEED ANALYSIS FOR AUDIO MEDIA OF CHARACTER-EDUCATION STORY FOR EARLY-AGED CHILDREN}

\author{
Suparti dan Mariana Susanti \\ Balai Pengembangan Media Radio Pendidikan dan Kebudayaan (BPMRPK)-Kemendikbud \\ Jl. Sorowajan Baru 367 Banguntapan, Yogyakarta, Indonesia \\ suparti@kemdikbud.go.id; mariana.susanti@kemdikbud.go.id
}

Diterima tanggal: 25 Agustus 2016, dikembalikan untuk direvisi tanggal: 12 September 2016, disetujui tanggal 18 September 2016

\begin{abstract}
ABSTRAK: Metode pembelajaran yang banyak digunakan tenaga pendidik di PAUD/TK adalah bermain dengan slogan 'bermain sambil belajar'. Selain metode bermain, ada metode bercerita dan bernyanyi. Metode bercerita merupakan salah satu metode yang efektif untuk memperkenalkan nilai-nilai mulia pada anak usia dini. Tujuan penelitian ini adalah mendapatkan data dan informasi mengenai: (1) kemampuan guru dalam bercerita; (2) kebutuhan guru akan media audio cerita pendidikan karakter untuk PAUD; (3) media audio pendidikan karakter untuk PAUD; dan (4) nilai-nilai pendidikan karakter yang bisa disampaikan melalui media audio bercerita. Penelitian ini dilakukan pada bulan Juni 2016. Populasi penelitian adalah guru-guru TK di Propinsi DIY. Sebanyak 20 guru TK menjadi sampel penelitian ini dengan menggunakan teknik simple random sampling. Instrumen kuesioner dan panduan wawancara digunakan untuk menjaring kebutuhan guru PAUD akan media audio cerita pendidikan karakter untuk anak usia dini. Data dianalisis menggunakan metode deskriptif kualitatif. Hasil penelitian menunjukkan bahwa: (1) kemampuan guru dalam bercerita cukup baik meskipun masih memiliki keterbatasan; (2) guru membutuhkan media audio yang dapat digunakan untuk menanamkan nilai-nilai karakter; (3) media audio pendidikan karakter yang dibutuhkan adalah cerita binatang; dan (4) nilai-nilai pendidikan karakter yang disampaikan mengacu pada kurikulum PAUD 2013. Dengan demikian, hasil penelitian menegaskan bahwa guru membutuhkan media audio dalam bentuk cerita binatang untuk membantu menanamkan nilai-nilai karakter pada anak usia dini.
\end{abstract}

Kata Kunci: cerita, media audio, pendidikan karakter.

\begin{abstract}
The learning methods that are most widely used by kindergarten teachers is 'by playing'. It is in accordance with their popular slogan 'learning while playing'. Beside in playing, learning can also be carried out in story telling or singing activities. Storyteling is an effective method that can be applied to introduce noble values to early-aged children. The purpose of this research is to get data and information about: (1) teachers' ability of conducting storytelling; (2) teachers' need for audio media on character education story for early-aged children; (3) audio media on character education story for early-aged children; and (4) moral values that can be delivered through audio media of storytelling. This research was done in June 2016. The population of this research was kindergarten teachers in Yogyakarta Province. The sample, 20 teachers, were taken by using simple random sampling. This research applies qualitative descriptive method by using questionnaire and interview guidance to get to know the need of early-aged children teachers. The result shows that: (1) the teachers' storytelling ability is good enough; (2) there is a need of audio media for the teachers to deliver character education; (3) the audio media required is about fables; and (4) the character values delivered refer to the 2013 curriculum of early-aged education. Based on the finding, teachers need fable audio media for them to deliver character value education to early-aged children.
\end{abstract}

Keywords: story, audio media, character education. 


\section{PENDAHULUAN}

Perkembangan ilmu dan teknologi yang begitu cepat telah menjadikan persaingan sumber daya manusia semakin tajam. Membekali peserta didik dengan pengetahuan dan keterampilan saja tidaklah cukup. Yang tidak kalah penting adalah membekali peserta didik dengan karakter yang kuat, gigih, dan kreatif. Oleh karena itu, dalam setiap jenjang pendidikan, pengembangan kompetensi sikap, pengetahuan, dan keterampilan dengan komposisi yang berbeda sangat diperlukan. Semakin awal jenjang pendidikan, semakin besar komposisi pengembangan kompetensi sikap (Kemdikbud, 2015) Dengan demikian, pendidikan karakter perlu ditanamkan sejak awal atau sejak usia dini. Oleh karena itu, pengembangan karakter perlu direncanakan secara matang dan terus-menerus sehingga membentuk kebiasaan dan yang pada akhirnya menjadi perilaku dan sikap dalam kehidupan sehari-hari.

Mengingat begitu pentingnya pengembangan dan penanaman nilai-nilai karakter sejak usia dini, sebagai sebuah institusi yang memiliki tugas dan fungsi untuk mengembangkan model dan format media audio radio untuk pendidikan dan kebudayaan, Balai Pengembangan Media Radio Pendidikan dan Kebudayaan (BPMRPK) memiliki andil untuk ikut mendukung upaya tersebut. Salah satu upaya tersebut adalah melalui pengembangan model-model media audio pendidikan untuk Pendidikan Anak Usia Dini (PAUD).

Dalam rangkaian kegiatan pengembangan model media audio tersebut, tahapan awal yang dilakukan adalah kegiatan Analisis Kebutuhan (Need Assessment). Analisis kebutuhan adalah sebuah sarana untuk mendefinisikan dan menentukan prioritas. Kebutuhan didefinisikan sebagai sebuah kesenjangan antara hasil yang ada dan hasil yang diharapkan. Hasil yang didapatkan selanjutnya menurut Watkins, Meiers, dan Visser (2012) dapat digunakan untuk membuat sebuah keputusan . Jadi, kegiatan analisis kebutuhan merupakan sebuah proses untuk mendefinisikan apa yang dibutuhkan calon pengguna sesuai dengan karakteristik dan kebutuhan mereka.
Kegiatan analisis kebutuhan pada dasarnya terbagi dalam dua tahapan, yaitu analisis kebutuhan di lapangan dan analisis kurikulum. Analisis kebutuhan di lapangan adalah sebuah proses untuk mengidentifikasi permasalahan pembelajaran, menentukan tujuan pembelajaran, mengetahui pengetahuan awal calon pengguna dan karakteristiknya. Sementara itu, analisis kurikulum merupakan sebuah proses untuk memetakan kurikulum dan mengidentifikasi karakteristik materi ajar, menentukan kompetensi, standar tingkat pencapaian perkembangan anak, dan menentukan isi dan karakteristik sesuai dengan karakteristik media (Suparti, 2007). Kegiatan analisis kurikulum ini biasanya diwadahi dalam sub tahapan kegiatan berikutnya yaitu pemetaan kompetensi dan materi dalam kurikulum.

Dalam konteks kegiatan analisis kebutuhan, BPMRPK berkepentingan untuk mengadakan penelitian dalam rangka mengembangakan model dan format sajian media audio pendidikan sesuai dengan kebutuhan calon pengguna di lapangan. Oleh karena itu, BPMRPK perlu menyelenggarakan sebuah studi atau analisis terkait kebutuhan media audio yang benar-benar dibutuhkan oleh calon pengguna. Salah satu media audio yang dikembangkan untuk mendukung pembelajaran anak usia dini adalah media audio pendidikan karakter. Hal ini didasari pada rasionalitas bahwa pembentukan karakter perlu dilakukan sejak usia dini.

Pendidikan karakter bukanlah sebuah proses menghafal materi ujian dan bagaimana teknik menjawabnya, namun memerlukan pembiasaan yang perlu dilakukan sejak usia dini. Pembiasaan itu antara lain untuk berbuat baik, berlaku jujur, sportif, malu berbuat curang, malu bersikap malas, malu membiarkan lingkungan kotor, dan lain sebagainya. Selama ini, masih ada kesenjangan antara praktik pendidikan dengan karakter anak didik (Husaini, 2010). Penjelasan tersebut mengandung pesan bahwa penanaman nilai-nilai dalam pendidikan karakter perlu dilakukan melalui pembiasaan sejak anak-anak masih berusia dini. Alasannya adalah bahwa penanaman nilai-nilai karakter pada masa kecil akan berpengaruh terhadap pertumbuhan fisik 
dan perkembangan jiwa anak ketika dewasa kelak.

Beberapa metode pengajaran di PAUD yang lazim disampaikan melalui media audio adalah metode bercerita, bermain, dan bernyanyi. Ketiga metode tersebut merupakan bahan dasar, yang dalam pengolahannya dapat dikemas sedemikian rupa sehingga akan menjadi model yang tepat sesuai dengan kebutuhan calon pengguna. Seiring dengan kebijakan pemerintah Republik Indonesia yang menekankan pentingnya pendidikan karakter bagi anak usia dini. Banyak penelitian di bidang keguruan dan ilmu pendidikan yang memfokuskan diri pada pendidikan karakter melalui berbagai metode pembelajaran untuk anak usia dini. Salah satu penelitian mengenai metode bercerita untuk mengajarkan nilai-nilai karakter yang baik kepada anak usia dini dengan judul "Upaya Meningkatkan Tanggungjawab Anak dengan Metode Bercerita Bermedia Audio Visual pada Kelompok A di RA Sholichah Gempolan Kulon Trirenggo Bantul Tahun Ajaran 2013/2014" (Purwanti, 2014).

Tujuan penelitian ini adalah untuk mengetahui seberapa besar peningkatan tangungjawab anak dengan bercerita menggunakan media audio visual pada kelompok $A$ dan mendeskripsikan pelaksanaan metode bercerita bermedia audio visual untuk meningkatkan tanggungjawab anak pada kelompok A di RA Sholichah, Gempolan Kulon, Trirenggo Bantul. (Purwanti, 2014) Penelitian ini adalah penelitian tindakan kelas (PTK) yang bersifat kualitatif.

Pengumpulan data dilakukan dengan pengamatan, wawancara, tes, dan dokumentasi. Keabsahan data dilakukan dengan menggunakan teknik triangulasi sumber. Hasil penelitian menunjukkan bahwa metode bercerita bermedia audio visual dapat meningkatkan tanggungjawab anak kelompok A di RA Sholichah Gempolan Kulon Trirenggo, Bantul. Hal tersebut terbukti berdasarkan hasil observasi dan tes pada Siklus 1 dan 2 yang menunjukkan adanya peningkatan signifikan pada anak yang mau melakukan tanggungjawab tanpa disuruh (82,72\%), adanya penurunan yang signifikan pada anak yang memerlukan bimbingan $(9,09 \%)$ dan anak yang belum melakukan tanggungjawabnya $(18,18 \%)$.
Penelitian yang lain dengan judul "Meningkatkan Karakter Kemandirian melalui Cerita Video pada Anak Kelompok B PAUD Al-Mujadid Kota Lubuklinggau."Penelitian ini membatasi fokus penelitian pada kegiatan pembelajaran tentang kemandirian, yang meliputi kemampuan melakukan sesuatu tanpa bantuan, berani tampil di depan orang, dan tanggung jawab untuk merapikan perlengkapan makan (Rita, 2014). Tujuan penelitian ini adalah untuk meningkatkan kemandirian anak Kelompok B di PAUD Al-Mujadid Lubuklinggau melalui cerita video.

Hasil penelitian menunjukkan bahwa pada Siklus 1 aspek kemampuan melakukan sesuatu tanpa bantuan adalah sebesar $40 \%$, dan pada Siklus 2 meningkat menjadi $85 \%$. Sementara itu, untuk aspek berani tampil di depan orang sebesar $45 \%$ meningkat menjadi 85\%, dan untuk aspek tanggung jawab merapikan perlengkapan makan sebesar 50\% meningkat menjadi 90\% (Rita, 2014). merekomendasikan kepada guru-guru PAUD untuk dapat meningkatkan karakter kemandirian anak melalui cerita video dengan tepat.

Penelitian berikutnya yang menarik untuk dipelajari adalah berjudul "Keefektifan Metode Penanaman Moral Bermuatan Pendidikan Karakter bagi Siswa Pendidikan Anak Usia Dini di Kota Semarang." (Shufiyati, 2013). Penelitian bertujuan untuk mengetahui keefektifan metode penanaman nilai moral yang bermuatan pendidikan karakter, metode penanaman moral, dan kendala yang dihadapi guru atau pendidik dalam menggunakan metode penanaman moral kepada anak usia dini di Kota Semarang. Metode yang digunakan adalah kuantitatif menggunakan metode pengumpulan data wawancara, dokumentasi, angket, dan observasi kepada kepala sekolah, guru, dan orang tua siswa. Hasil penelitian menunjukkan bahwa keefektifan metode penanaman moral bermuatan pendidikan karakter bagi siswa PAUD berada pada kategori tinggi $(63,63 \%)$. Metode penanaman moral yang bermuatan pendidikan karakter adalah metode bernyanyi, bercerita, tanya jawab, pembiasaan dalam perilaku, dan karyawisata. Kendala yang 
dihadapi guru atau pendidik dalam menggunakan metode penanaman moral adalah faktor internal dan eksternal. Faktor internal tersebut berupa penggunaan metode bercerita terutama ketersediaan alat peraga dan buku cerita; sementara dari faktor eksternal adalah kurangnya sarana dan prasarana yang dimiliki sekolah, kesulitan anak untuk mengikuti perintah orangtua di rumah, terutama nilai agama dan moral.

Berdasarkan penelitian yang telah dilakukan sebelumnya, penelitian ini memfokuskan diri pada penanaman nilai moral dengan menggunakan metode bercerita dalam bentuk media audio.

Beberapa permasalahan yang akan dijawab dalam penelitian ini dirumuskan dalam serangkaian pertanyaan, yaitu: (1) seperti apakah kemampuan guru dalam bercerita kepada anak PAUD?; (2) apakah kebutuhan guru akan media audio cerita pendidikan karakter untuk menunjang pembelajaran di PAUD?; (3) seperti apakah model media audio cerita pendidikan karakter yang diperlukan?; (4) nilai-nilai karakter apa sajakah yang dapat disajikan melalui media audio tersebut?

Tujuan penelitian ini adalah untuk mendapatkan data dan informasi mengenai: (1) kemampuan guru dalam bercerita kepada anak PAUD; (2) kebutuhan guru akan media audio cerita pendidikan karakter untuk mendukung pembelajaran di PAUD; (3) model media audio pendidikan karakter untuk PAUD, dan (4) nilai-nilai pendidikan karakter yang bisa disampaikan melalui media audio dengan metode bercerita.

Bagi BPMRPK, penelitian ini bermanfaat untuk mengembangkan model media audio cerita pendidikan karakter yang benar-benar dibutuhkan dalam mendukung pembelajaran di PAUD. Sementara bagi Pengembang Teknologi Pembelajaran, penelitian ini bermanfaat untuk memberikan data dan informasi mengenai kebutuhan media audio cerita pendidikan karakter dalam mendukung pembelajaran di PAUD.

\section{KAJIAN LITERATUR}

\section{Pengertian Analisis Kebutuhan}

Analisis merupakan tahapan di mana permasalahan diidentifikasi, dan kebutuhan serta tujuan pembelajaran ditetapkan. Tahapan ini akan memberikan blueprint atau cetak biru dalam keseluruhan prosedur pengembangan media pada tahapan selanjutnya (Davis, 2013). Analisis merupakan tahapan pertama dalam prosedur pengembangan media. Salah satu kegiatan yang dilakukan dalam tahapan ini adalah analisis kebutuhan.

Analisis kebutuhan merupakan sebuah pendekatan sistematik untuk mempelajari pengetahuan, kemampuan, atau sikap, dari calon pengguna terhadap sebuah kebutuhan akan produk atau program tertentu. Analisis kebutuhan merupakan sebuah metode untuk mempelajari apa yang telah dilakukan dan kesenjangan kebutuhan apa yang ada pada calon pengguna. Hal ini memungkinkan pendidik atau perancang untuk dapat menentukan keputusan yang tepat tentang program atau produk yang benar-benar dibutuhkan dan perlu dikembangkan (McCawley, 2009).

Dalam pengertian lain, analisis kebutuhan didefinisikan sebagai sebuah prosedur sistematik yang digunakan untuk menentukan kebutuhan, menguji sifat dan penyebabnya, serta skala prioritas untuk menentukan tindakan di masa depan. Kegiatan ini dilakukan untuk membantu perencana program mengidentifikasi dan memilih tugas atau pekerjaan yang tepat sebelum melakukannya (Office of Migrant Education, 2001).

Sementara itu, beberapa tahapan yang perlu dilakukan dalam kegiatan analisis kebutuhan antara lain: mengidentifikasi materi/pokok pembelajaran, mengidentifikasi media/alat bantu yang digunakan, mengidentifikasi hasil belajar dan target yang akan dicapai, mengidentifikasi karakteristik pebelajar, dan sebagainya (Jaliusril, dkk. 2012).

Dengan demikian, analisis kebutuhan merupakan sebuah proses yang berkelanjutan dalam rangka pengumpulan data dan informasi mengenai kesenjangan antara kondisi riil dan kondisi ideal guna menentukan kebutuhan akan model produk atau 
program yang tepat bagi calon pengguna.

\section{Media Audio Pendidikan}

Dalam kehidupan sehari-hari, komunikasi auditif mendominasi kehidupan manusia. Demikian juga dalam kegiatan pembelajaran di mana komunikasi audio banyak digunakan. Audio atau radio merupakan media pembelajaran yang berbasis bunyi atau suara. Audio sendiri berasal dari kata audible yang artinya suara yang dapat didengarkan secara wajar oleh telinga manusia (Waldopo, 2008). Istilah media mengacu kepada segala sesuatu yang dapat digunakan untuk menyampaikan pesan.

Dalam pengertian lain, media audio pendidikan dapat diartikan sebagai bahan yang mengandung pesan dalam bentuk auditif atau suara yang dapat merangsang pikiran, perasaan, dan kemauan anak didik sehingga terjadi proses belajar mengajar (Haryono, 2006). Dengan demikian, media audio pendidikan adalah semua jenis program yang dalam penyampaiannya menggunakan unsur suara untuk menyampaikan isi atau materi pembelajaran. Unsur suara pada dasarnya bisa diurai dalam tiga hal, yaitu: (1) unsur tutur, misalnya dialog, narasi, atau pun cerita (yang bisa dikombinasi dengan); (2) unsur music; dan (3) unsur efek suara untuk menghidupkan atmosfir dan suasana.

Beberapa kelebihan dari media audio antara lain jangkauannya yang relatif luas, fleksibel, dapat digunakan untuk memusatkan perhatian, dan dapat menciptakan daya imajinasi bagi pendengar (Smaldino dkk: 2008). Namun demikian, media audio juga memiliki kekurangan, yaitu antara lain sifatnya searah sehingga bila ada hal-hal yang kurang jelas peserta didik tidak bisa bertanya kepada guru audionya (Daryanto, 2016: 39).

\section{Pendidikan Karakter untuk PAUD}

Pendidikan karakter terdiri atas dua kata: pendidikan dan karakter. Dalam UU Nomor 20 Tahun 2003 tentang Sistem Pendidikan Nasional, Pasal 1 ayat (1) menyatakan bahwa pendidikan adalah usaha sadar dan terencana untuk mewujudkan suasana belajar dan proses pembelajaran agar anak didik secara aktif mengembangkan potensi dirinya untuk memiliki kekuatan spiritual keagamaan, pengendalian diri, kepribadian, kecerdasan, akhlak mulia, serta keterampilan yang diperlukan dirinya, masyarakat, bangsa dan negara. Sementara itu, menurut Kamus Besar Bahasa Indonesia (2008), karakter berarti sifatsifat kejiwaan, akhlak atau budi pekerti yang membedakan seseorang dari yang lain. Menurut pengertian lain, karakter juga diartikan sebagai kualitas mental atau moral, akhlak atau budi pekerti individu yang merupakan kepribadian khusus yang menjadi pendorong dan penggerak, serta membedakannya dengan individu lain (Muhtadi, 2010).

Pendidikan karakter bukanlah sekadar pendidikan moral yang mengajarkan mana yang benar dan yang salah, namun juga mengintegrasikan nilai-nilai yang baik dalam diri anak sehingga menyatu dalam perilaku mereka sehari-hari. Oleh karena itulah pendidikan karakter sebaiknya diterapkan pada anak sejak usia dini. Tujuan penanaman sikap sejak usia dini adalah untuk: (1) membangun pemahaman anak tentang sikap, nilai, dan perilaku baik; (2) membiasakan anak melakukan dan menerapkan sikap yang baik; dan (3) membangun karakter anak yang mendukung keberhasilan di jenjang pendidikan selanjutnya (Kemdikbud, 2015).

Pendidikan karakter merupakan sebuah upaya untuk menghasilkan anak didik yang bukan hanya cerdas secara akademik, namun juga bermoral dan berpribadi yang baik. Penerapan pendidikan karakter sejak usia dini merupakan sebuah langkah yang tepat karena masa keemasan (golden age) merupakan saat yang tepat untuk meletakkan dasar nilai karakter yang baik untuk mendukung perkembangan anak di masa berikutnya. Dengan pengembangan karakter yang baik, anak akan tumbuh menjadi pribadi yang baik dan mulia. Agar pendidikan karakter mengena di hati anak, dibutuhkan sebuah metode pendidikan karakter yang tepat bagi anak usia dini, salah satunya melalui bercerita. Hal ini sangat relevan karena anak usia dini cenderung memiliki daya imajinasi yang tinggi (Nuryanto, 2015: 108). 


\section{Kompetensi Sikap dalam Kurikulum 2013 untuk PAUD}

Penanaman sikap pada pendidikan anak usia dini memiliki peran yang sangat penting dalam membangun karakter anak sejak dini. Penanaman sifat ini dapat dilakukan melalui pembiasaan dan keteladanan. Tidak mengherankan apabila penanaman sikap menempati prioritas utama dibandingkan dengan pengembangan pengetahuan dan keterampilan. Pengembangan sikap, seperti tertuang dalam kurikulum 2013 PAUD, mencakup seluruh aspek perkembangan, yaitu aspek nilai agama dan moral, fisik motorik, kognitif, sosial-emosional, bahasa dan seni. Dalam struktur kurikulum 2013, pengembangan sikap ini mencakup kompetensi inti sikap spiritual-KI.1 Spiritual dan Kompetensi Inti Sikap Sosial-KI.2 Sosial. Yang termasuk dalam KI.1 Sikap Spiritual adalah "Menerima ajaran agama yang dianutnya" dan "Mencerminkan kecerdasan spiritual sebagai sikap kesadaran mengenal agama yang dianutnya." Sementara itu yang termasuk dalam KI.2 Sikap Sosial adalah "Memiliki perilaku hidup sehat, rasa ingin tahu, kreatif dan estetis, percaya diri, disiplin, mandiri, peduli, mampu bekerjasama, mampu menyesuaikan diri, jujur, dan santun dalam berinteraksi dengan keluarga, pendidik dan/atau pengasuh, dan teman. Mencerminkan kecerdasan sosial-emosional sebagai sikap dan perilaku yang mengenal perasaan diri, orang lain, dan nilai-nilai sosial yang sesuai dengan norma serta budaya yang berlaku." (Kemdikbud, 2015).

Kompetensi Inti Sikap ini selanjutnya dikembangkan menjadi Kompetensi Dasar (KD) yang memuat berbagai nilai-nilai karakter yang diharapkan akan tercapai di akhir program PAUD. Berikut tabel KD dalam struktur kurikulum PAUD 2013 (Tabel 1).

Tabel 1. Kompetensi Inti Sikap dalam Kurikulum 2013 untuk PAUD

\section{Kompetensi Dasar 1 Sikap Spiritual terdiri dari:}

KD 1.1 Mempercayai adanya Tuhan melalui ciptaan-Nya KD 1.2 Menghargai diri sendiri, orang lain, dan lingkungan sekitar sebagai rasa syukur kepada Tuhan

\section{Kompetensi Dasar 2 Sikap Sosial terdiri dari:}

KD.2.1 Memiliki perilaku yang mencerminkan hidup sehat KD.2.2 Memiliki perilaku yang mencerminkan sikap ingin tahu KD.2.3 Memiliki perilaku yang mencerminkan sikap kreatif
KD.2.4 Memiliki perilaku yang mencerminkan sikap estetis KD.2.5 Memiliki perilaku yang mencerminkan sikap percaya diri KD.2.6 Memiliki perilaku yang mencerminkan sikap taat terhadap aturan sehari-hari untuk melatih kedisiplinan

KD.2.7 Memiliki perilaku yang mencerminkan sikap sabar (mau menunggu giliran, mau mendengar ketika orang lain berbicara) untuk melatih kedisiplinan

KD.2.8 Memiliki perilaku yang mencerminkan kemandirian

KD.2.9 Memiliki perilaku yang mencerminkan sikap peduli dan mau membantu jika diminta bantuannya

KD.2.10 Memiliki perilaku yang mencerminkan sikap menghargai dan toleran kepada orang lain

KD.2.11 Memiliki perilaku yang dapat menyesuaikan diri

KD.2.12 Memiliki perilaku yang mencerminkan sikap tanggung jawab

KD.2.13 Memiliki perilaku yang mencerminkan sikap jujur

KD.2.14 Memiliki perilaku yang mencerminkan sikap rendah hati dan santun kepada orang tua, pendidik, dan teman

Sebagaimana halnya pengembangan kompetensi pengetahuan dan keterampilan, pengembangan kompetensi sikap harus direncanakan dan diterapkan dengan secermat mungkin, agar sikap yang terbangun pada anak sesuai dengan yang diharapkan. Hal ini karena pengembangan kompetensi sikap yang direncanakan dengan baik akan mendorong terbentuknya karakter sejak usia dini (Kemdikbud, 2015).

Ada banyak kualitas karakter yang dapat dikembangkan, namun secara singkat dapat didasarkan pada 9 pilar karakter yang memuat nilai-nilai luhur yang universal. Kesembilan pilar karakter tersebut yaitu: (1) cinta Tuhan dan alam semesta beserta isinya; (2) tanggung jawab, kedisiplinan, dan kemandirian; (3) kejujuran; (4) hormat dan santun; (5) kasih sayang, kepedulian, dan kerjasama; (6) percaya diri, kreatif, kerja keras, dan pantang menyerah; (7) keadilan dan kepemimpinan; (8) baik dan rendah hati; dan (9) toleransi, cinta damai, dan persatuan. Metode penanaman nilai karakter ini dilakukan secara sistematis agar anak terbiasa berpikir yang baik, tahu mengapa dia harus berbuat baik, misalnya tahu kenapa dia harus jujur, apa akibatnya jika dia tidak jujur, dan lain sebagainya. Dengan demikian, anak bukan hanya menghafalkan nilai-nilai kebaikan melainkan juga mengetahui alasan mengapa ia harus berbuat baik. Selain itu perasaan anak perlu dibangun agar ia mencintai kebaikan dan mempraktikkannya sehingga lama kelamaan akan terbentuk karakternya (Megawangi, tt: 5). 


\section{Bercerita untuk Anak Usia Dini}

Bercerita adalah kegiatan menyampaikan kisah atau cerita kepada anak melalui kata-kata, yang dapat diselingi dengan lagu atau hal menarik lainnya. Karena itu, metode bercerita penting diterapkan dalam pembelajaran untuk anak usia dini. Ada beberapa alasan yang melatarbelakanginya. Pertama, bercerita adalah metode komunikasi universal yang sangat berpengaruh kepada jiwa manusia. Metode ini sangat efektif untuk mempengaruhi jiwa anak-anak. Karena alasan inilah, mendidik dan menasehati anak melalui cerita adalah cara yang bijak dan cerdas. Selain itu, memberikan nasihat berupa cerita pada umumnya lebih berkesan daripada nasehat murni dan akan terekam jauh lebih kuat dalam memori manusia. Dengan cerita, anak dapat belajar untuk mengambil hikmah tanpa merasa digurui. Dengan kata lain, metode bercerita penting karena dapat dijadikan sebagai alat pendidikan budi pekerti yang paling mudah dicerna anak, di samping keteladanan yang dapat dilihat anak dalam kehidupan sehari-hari.

Dengan bercerita, anak dapat mengembangkan kemampuan bersimpati dan berempati terhadap peristiwa yang menimpa orang lain. Anak mendapatkan contoh bagaimana menyikapi suatu permasalahan dengan baik, melakukan pembicaraan yang baik, memiliki barometer sosial (seperti patuh pada perintah orangtua, mengalah pada adik, selalu bersikap jujur, membangkitkan rasa tahu anak, dan memberikan dorongan pada anak untuk belajar menelaah kejadiankejadian sekelilingnya) (Cholimah, 2016).

Dalam bercerita, seorang guru dapat memanfaatkan berbagai media yang dapat mendukung kejelasan dan kemenarikan cerita. Dengan memanfaatkan media dalam bercerita, guru akan terbantu dalam menyampaikan pesan cerita. Cerita yang menarik bagi anak adalah cerita yang bersumber dari pengalaman sehari-hari atau hal-hal sederhana yang mudah dicerna anak. Cara penuturannya pun harus menarik sehingga anak akan terfokus untuk mendengarkan cerita yang disampaikan. Bercerita juga dapat membantu perkembangan imajinasi anak. Dengan bercerita anak akan belajar tentang bahasa, mengenal berbagai emosi dan perasaan (Rahmawati, 2012).
Jadi, bercerita juga merupakan sarana efektif untuk mengenalkan nilai-nilai baik dan buruk yang bermanfaat dalam menanamkan pendidikan karakter pada anak. Teknik bercerita pun dapat disampaikan melalui media, misalnya media audio. Cerita yang disampaikan hendaknya juga menarik dan bersumber dari pengalaman hidup dalam keseharian anak. Cerita yang disampaikan hendaknya juga mengandung nilainilai kehidupan yang mudah dicerna anak.

\section{METODE PENELITIAN}

Penelitian ini menggunakan metode deskriptif kualitatif dengan instrumen kuesioner sejumlah 18 item pertanyaan. Ke-18 item pertanyaan tersebut disusun berdasarkan 3 aspek tentang kebutuhan media audio, yaitu: aspek edukatif, teknis dan penyampaian, serta estetis. Tabel 2 menggambarkan persebaran item pertanyaan untuk menjawab tujuan penelitian ini, yaitu kemampuan guru dalam bercerita untuk anak PAUD, kebutuhan guru akan media audio cerita pendidikan karakter yang dapat membantu guru dalam menunjang pembelajaran di PAUD, media audio cerita pendidikan karakter yang sesuai, dan nilai-nilai karakter apa saja yang dapat disajikan melalui media audio tersebut (Tabel 2).

Tabel 2. Kisi-kisi instrumen penelitian

\begin{tabular}{|c|c|c|c|}
\hline Tujuan Penelitian & Pertanyaan & $\begin{array}{l}\text { Butir } \\
\text { ke- }\end{array}$ & $\begin{array}{l}\text { Pilihan } \\
\text { Jawaban }\end{array}$ \\
\hline $\begin{array}{l}\text { Kemampuan guru } \\
\text { dalam bercerita } \\
\text { untuk anak PAUD }\end{array}$ & $\begin{array}{l}\text { Kemampuan } \\
\text { guru PAUD } \\
\text { dalam bercerita? }\end{array}$ & 12 & $\begin{array}{l}\text { Sangat bagus/ } \\
\text { bagus/cukup/ } \\
\text { kurang }\end{array}$ \\
\hline \multirow[t]{2}{*}{$\begin{array}{l}\text { Kebutuhan guru } \\
\text { akan media audio } \\
\text { cerita pendidikan } \\
\text { karakter yang dapat } \\
\text { membantu guru } \\
\text { dalam menunjang } \\
\text { pembelajaran di } \\
\text { PAUD }\end{array}$} & $\begin{array}{l}\text { Metode } \\
\text { pembelajaran } \\
\text { apa yang Anda } \\
\text { gunakan untuk } \\
\text { mengajar? }\end{array}$ & 1 & $\begin{array}{l}\text { Bercerita/ } \\
\text { Bernyanyi/ } \\
\text { Bermain/ } \\
\text { Berdialog/ } \\
\text { Demonstrasi/ } \\
\text { Karya Wisata/ } \\
\text { Lainnya }\end{array}$ \\
\hline & $\begin{array}{l}\text { Jika } \\
\text { menggunakan } \\
\text { metode } \\
\text { bercerita, teknik } \\
\text { bercerita seperti } \\
\text { apa yang } \\
\text { digunakan? }\end{array}$ & 2 & $\begin{array}{l}\text { Bercerita secara } \\
\text { langsung/ } \\
\text { Membacakan } \\
\text { buku cerita/ } \\
\text { Boneka jari/ } \\
\text { Cerita } \\
\text { bergambar/ } \\
\text { media audio } \\
\text { visual/ media } \\
\text { audio/ lainnya }\end{array}$ \\
\hline
\end{tabular}




\begin{tabular}{|c|c|c|c|}
\hline Tujuan Penelitian & Pertanyaan & $\begin{array}{l}\text { Butir } \\
\text { ke- }\end{array}$ & $\begin{array}{l}\text { Pilihan } \\
\text { Jawaban }\end{array}$ \\
\hline & $\begin{array}{l}\text { Apakah Anda } \\
\text { pernah } \\
\text { memanfaatkan } \\
\text { media audio } \\
\text { untuk } \\
\text { pembelajaran } \\
\text { di PAUD? }\end{array}$ & 3 & Ya/Tidak \\
\hline & $\begin{array}{l}\text { Jika pernah, } \\
\text { media audio } \\
\text { tersebut } \\
\text { dimanfaatkan } \\
\text { dalam } \\
\text { pembelajaran } \\
\text { yang } \\
\text { menggunakan } \\
\text { metode apa? }\end{array}$ & 4 & $\begin{array}{l}\text { Bernyanyi/ } \\
\text { Bercerita/ } \\
\text { Menari/ } \\
\text { Bermain/ } \\
\text { Lainnya }\end{array}$ \\
\hline \multirow[t]{5}{*}{$\begin{array}{l}\text { Model media audio } \\
\text { cerita pendidikan } \\
\text { karakter yang } \\
\text { sesuai }\end{array}$} & $\begin{array}{l}\text { Berdasarkan } \\
\text { jenisnya, } \\
\text { pilihlah jenis } \\
\text { cerita yang } \\
\text { cocok } \\
\text { disampaikan } \\
\text { untuk anak } \\
\text { PAUD. }\end{array}$ & 5 & $\begin{array}{l}\text { Fabel/ cerita } \\
\text { rakyat/ cerita } \\
\text { keagamaan/ } \\
\text { biografi/ fiksi }\end{array}$ \\
\hline & $\begin{array}{l}\text { Apakah } \\
\text { pendidikan } \\
\text { karakter untuk } \\
\text { PAUD cocok } \\
\text { disampaikan } \\
\text { melalui cerita? }\end{array}$ & 6 & Ya/ Tidak \\
\hline & $\begin{array}{l}\text { Apakah } \\
\text { materi cerita } \\
\text { perlu } \\
\text { mengacu } \\
\text { pada tema } \\
\text { tertentu? }\end{array}$ & 8 & Ya/Tidak \\
\hline & $\begin{array}{l}\text { Tokoh cerita } \\
\text { seperti apa } \\
\text { yang } \\
\text { biasanya } \\
\text { disukai } \\
\text { anak? }\end{array}$ & 9 & $\begin{array}{l}\text { Tokoh fiktif } \\
\text { berupa } \\
\text { binatang/ tokoh } \\
\text { fiktif berupa } \\
\text { manusia/ tokoh } \\
\text { fiktif dalam } \\
\text { dunia imajiner/ } \\
\text { gabungan dari } \\
\text { ketiganya }\end{array}$ \\
\hline & $\begin{array}{l}\text { Bagaimanakah } \\
\text { bahasa yang } \\
\text { sebaiknya } \\
\text { digunakan } \\
\text { dalam } \\
\text { bercerita untuk } \\
\text { anak PAUD? }\end{array}$ & 10 & \\
\hline
\end{tabular}

\begin{tabular}{|c|c|c|c|}
\hline Tujuan Penelitian & Pertanyaan & $\begin{array}{l}\text { Butir } \\
\text { ke- }\end{array}$ & $\begin{array}{l}\text { Pilihan } \\
\text { Jawaban }\end{array}$ \\
\hline & $\begin{array}{l}\text { Pesan/amanat } \\
\text { cerita yang } \\
\text { mengandung } \\
\text { pendidikan } \\
\text { karakter perlu } \\
\text { ditegaskan } \\
\text { secara eksplisit } \\
\text { di akhir cerita. }\end{array}$ & 11 & \\
\hline & $\begin{array}{l}\text { Media audio } \\
\text { cocok digunakan } \\
\text { dalam } \\
\text { menyampaikan } \\
\text { cerita. }\end{array}$ & 13 & $\begin{array}{l}\text { Setuju/ Tidak } \\
\text { Setuju }\end{array}$ \\
\hline & $\begin{array}{l}\text { Durasi } \\
\text { penyampaian } \\
\text { cerita melalui } \\
\text { media audio } \\
\text { untuk anak } \\
\text { PAUD adalah.... }\end{array}$ & 14 & $\begin{array}{l}\text { 5-7 menit/ } \\
8-10 \text { menit/ } \\
11-15 \text { menit }\end{array}$ \\
\hline & $\begin{array}{l}\text { Media audio } \\
\text { perlu dilengkapi } \\
\text { dengan } \\
\text { petunjuk } \\
\text { pemanfaatan. }\end{array}$ & 15 & Ya/Tidak \\
\hline & $\begin{array}{l}\text { Casing CD } \\
\text { media audio } \\
\text { yang dibuat } \\
\text { sebaiknya.... }\end{array}$ & 16 & $\begin{array}{l}\text { Cover program, } \\
\text { sinopsis, } \\
\text { petunjuk } \\
\text { pemanfaatan } \\
\text { menyatu } \\
\text { dengan CD } \\
\text { program/Cover } \\
\text { program, } \\
\text { sinopsis, } \\
\text { petunjuk } \\
\text { pemanfaatan } \\
\text { terpisah dari } \\
\text { CD program/ } \\
\text { Masukan lain }\end{array}$ \\
\hline & $\begin{array}{l}\text { Suara pencerita } \\
\text { dan tokoh } \\
\text { cerita harus } \\
\text { menarik. }\end{array}$ & 17 & Ya/Tidak \\
\hline & $\begin{array}{l}\text { Musik dan efek } \\
\text { suara } \\
\text { diperlukan untuk } \\
\text { mendukung } \\
\text { cerita. }\end{array}$ & 18 & Ya/Tidak \\
\hline $\begin{array}{l}\text { Nilai-nilai karakter } \\
\text { yang dapat } \\
\text { disajikan melalui } \\
\text { media audio }\end{array}$ & $\begin{array}{l}\text { Jika ya, nilai- } \\
\text { nilai karakter } \\
\text { apa yang } \\
\text { perlu } \\
\text { disampaikan } \\
\text { dalam cerita } \\
\text { itu? }\end{array}$ & & \\
\hline
\end{tabular}

Sumber: Kisi-kisi Instrumen Kuesioner 
Berdasarkan Tabel 2, dapat diketahui bahwa informasi yang ingin diketahui tentang kemampuan guru PAUD dalam bercerita disampaikan ke dalam 1 butir pertanyaan; sedangkan kebutuhan guru PAUD akan tersedianya media audio cerita pendidikan karakter diuraikan ke dalam 4 butir pertanyaan. Media audio cerita pendidikan karakter yang diinginkan guru PAUD didapatkan dari 12 butir pertanyaan yang tertulis di kuesioner. Informasi mengenai nilai-nilai pendidikan karakter yang dapat disampaikan melalui media audio didapatkan dari 1 butir pertanyaan.

Setelah responden mengisi kuesioner, peneliti melakukan wawancara untuk konfirmasi terhadap jawaban-jawaban yang sudah diberikan responden. Kegunaan lain dari wawancara adalah mendapatkan informasi yang lebih dalam selain dari yang dituliskan oleh responden di dalam kuesioner.

Populasi penelitian adalah guru TK di wilayah pedesaan. Sampel penelitian ini adalah guru TK di wilayah pedesaan yang ada di Kabupaten Bantul, Kabupaten Gunungkidul, dan Kabupaten Sleman Provinsi Daerah Istimewa Yogyakarta (DIY) yang menjadi peserta dalam Bimbingan Teknis Pemanfaatan Siaran Radio Pendidikan untuk Pendidikan Anak Usia Dini pada bulan Juni 2016. Teknik pengambilan sampel yang digunakan dalam penelitian ini adalah simple random sampling. Simple random sampling adalah cara pengambilan sampel dari anggota populasi secara acak tanpa memperhatikan strata atau tingkatan dalam anggota penelitian tersebut. Hal ini dilakukan apabila anggota populasi dianggap homogen atau sejenis (Riduwan dan Akdon, 2013:241).

Instrumen kuesioner dibagikan kepada 20 guru TK di kabupaten Bantul, Gunungkidul, dan Sleman Provinsi Daerah Istimewa Yogyakarta. Homogenitas responden adalah wilayah TK para responden samasama berada di pedesaan. Rincian sebaran ke-20 TK yang menjadi responden penelitian dituliskan dalam Tabel 3.

Tabel 3. Sebaran responden di Provinsi DIY

\begin{tabular}{ll}
\hline Kabupaten & Jumlah TK \\
\hline Bantul & 6 \\
\hline Gunungkidul & 10 \\
\hline Sleman & 4 \\
\hline Jumlah & 20 \\
\hline
\end{tabular}

Data dan informasi yang telah terkumpul dianalisis secara deskriptif kualitatif dengan menghitung nilai maksimum, nilai minimum, frekuensi, dan persentase jawaban berdasarkan scoring setiap jawaban dari responden.

\section{HASIL DAN PEMBAHASAN}

Bagian ini disusun untuk menjawab empat tujuan penelitian, yaitu: (1) kemampuan guru dalam bercerita; (2) kebutuhan guru akan media audio cerita pendidikan karakter untuk PAUD; (3) model dan format sajiian media audio pendidikan karakter untuk PAUD; dan (4) nilai-nilai pendidikan karakter yang bisa disampaikan melalui media audio bercerita.

Kemampuan Guru dalam Bercerita, salah satu tujuan penelitian ini adalah mengetahui kemampuan guru PAUD dalam bercerita. Hasil penelitian mengungkap bahwa sebanyak 35\% responden menyatakan bahwa kemampuan guru PAUD dalam bercerita cukup bagus, dan hanya $9 \%$ responden yang menyatakan kemampuan guru PAUD untuk bercerita masih kurang. Hal ini ditampilkan dalam Diagram 4 mengenai kemampuan guru PAUD dalam bercerita.

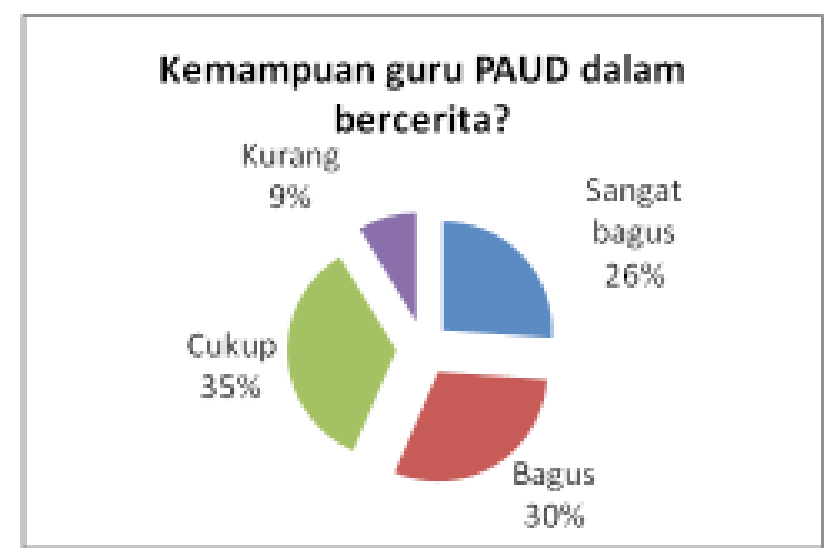

Diagram 4. Persentase Kemampuan Guru PAUD Dalam Bercerita Menurut Responden

Kebutuhan guru akan media audio cerita pendidikan karakter untuk PAUD. Metode pembelajaran anak usia dini merupakan cara-cara atau teknik yang digunakan agar tujuan pembelajaran tercapai. Penggunaan metode pembelajaran yang tepat dan sesuai dengan 
karakter anak akan dapat memfasilitasi perkembangan berbagai potensi dan kemampuan anak secara optimal. Dari beragam metode pembelajaran untuk anak usia dini, diketahui bahwa sebagian responden menggunakan metode bermain sebagai prioritas pertama dalam pembelajaran untuk anak usia dini. Hal ini tergambar dalam Diagram 5 mengenai metode pembelajaran yang dipakai responden dalam kegiatan pembelajaran anak usia dini. Bermain dianggap sebagai metode pembelajaran PAUD yang efektif dan menyenangkan karena dalam bermain, anak bisa melakukan aktivitas yang mempraktikkan kemampuan dan ketrampilannya dalam kegiatan mencoba, meneliti, dan menemukan hal-hal yang baru (Diagram 5).

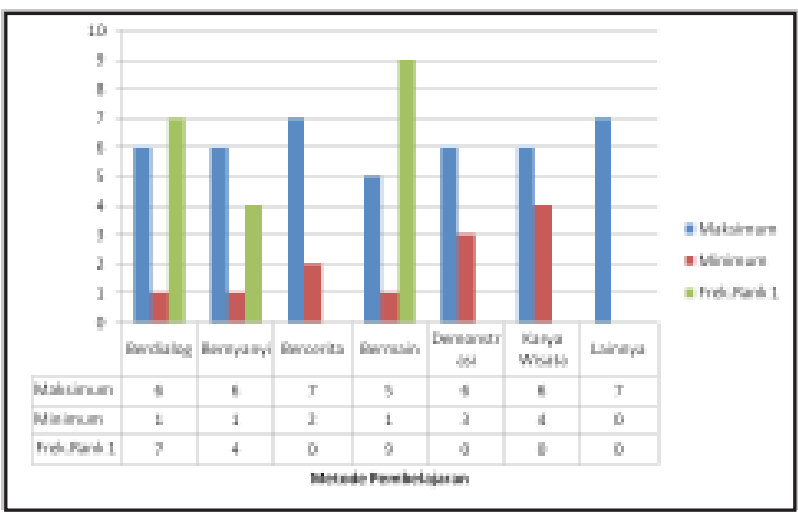

Diagram 5. Metode Pembelajaran yang digunakan Responden

Diagram 5 menunjukkan bahwa metode pembelajaran urutan kedua yang paling banyak dipilih responden adalah bercakap-cakap atau berdialog. Urutan berikutnya dalam metode pembelajaran untuk anak usia dini yang dipilih responden adalah bernyanyi. Temuan penelitian ini mengungkap bahwa metode bercerita tidak pernah dijadikan urutan pertama oleh responden. Hal ini dapat diketahui dari nilai minimum dan maksimum yang nampak adalah kisaran 2 sampai 7. Setelah dianalisis lebih lanjut ternyata tidak semua guru/ sekolah memiliki materi/media audio cerita untuk mendukung pembelajaran di PAUD. Padahal, metode bercerita merupakan salah satu pemberian pengalaman belajar bagi anak usia dini dengan membawakan cerita kepada anak secara menarik agar dapat mengundang perhatian anak.

Jika responden menggunakan metode bercerita, teknik bercerita yang paling banyak digunakan adalah bercerita secara langsung atau secara lisan kepada anak. Hal ini dapat dilihat dalam Diagram 6 mengenai teknik bercerita yang digunakan responden. Teknik berikutnya yang dipakai responden adalah membacakan buku cerita untuk anak, dan becerita dengan ilustrasi gambar dari buku. Hal yang menarik dari temuan penelitian ini adalah hampir semua responden menjadikan teknik bercerita menggunakan media audio di urutan keenam (Diagram 6).

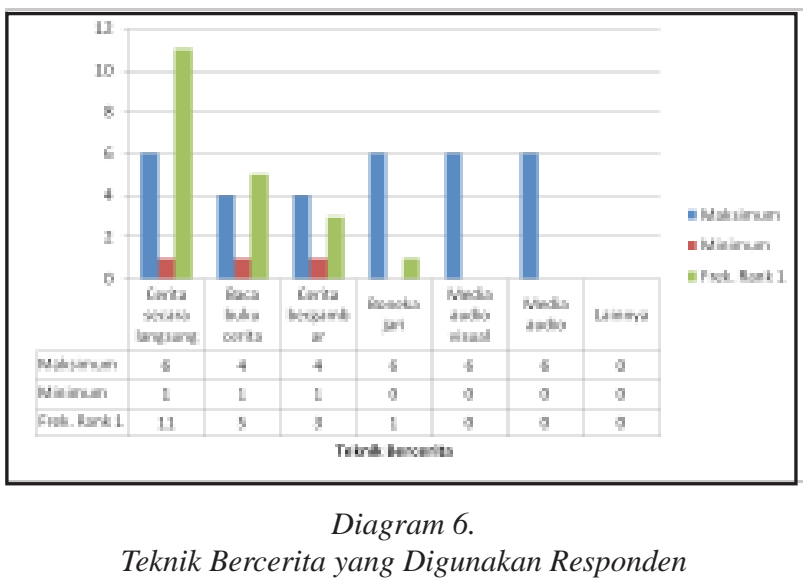

Sementara itu, sebanyak $63 \%$ responden menyatakan bahwa mereka pernah menggunakan media audio untuk pembelajaran. Menari dan bernyanyi adalah kegiatan pembelajaran yang paling banyak menggunakan media audio. Masing-masing kegiatan tersebut dipilih oleh $28 \%$ responden. Sementara itu, kegiatan bercerita menggunakan media audio dilakukan oleh 23\% responden, dan sisanya (21\%) menggunakan media audio untuk kegiatan bermain.

Model media audio pendidikan karakter untuk PAUD. Sementara itu, seluruh responden guru TK (100\%) menyatakan bahwa media audio cocok digunakan untuk menyampaikan cerita. Pendidikan karakter untuk anak usia dini, menurut semua responden (100\%), sesuai untuk disampaikan melalui cerita. Jenis cerita yang cocok untuk anak usia dini menurut sebagian besar responden adalah fabel. Haryati (2011) mengutip pengertian fabel 
menurut Gero Wilpert, yaitu secara etimologis, fabel berasal dari kata dalam bahasa Latin fibula, yang berarti cerita yang bertujuan untuk menyampaikan kebenaran, ajaran moral, atau kebijaksanaan hidup dengan melalui penggambaran makhluk-makhluk, baik itu hewan atau tumbuhan, maupun benda mati sebagai contoh yang dianalogkan mempunyai sikap, adat istiadat dan tingkah laku yang sama dengan manusia. Berdasarkan definisi tersebut, tokoh dalam fabel sebenarnya tidak hanya binatang, tetapi bisa juga tumbuhan atau benda mati lainnya (Haryati, 2011). Meski demikian, tokoh yang dominan dalam fabel adalah binatang sehingga fabel sering disebut cerita binatang.

Temuan berikutnya dalam penelitian ini mengungkap bahwa tokoh cerita yang disukai anak adalah gabungan antara tokoh fiktif berupa binatang, manusia, dan dunia imajiner yang memiliki watak, sikap, adat istiadat yang menyerupai manusia. Hal ini dinyatakan oleh 55\% responden guru TK yang secara jelas mengenai tokoh cerita yang disukai anak usia dini dapat dilihat pada Diagram 7.

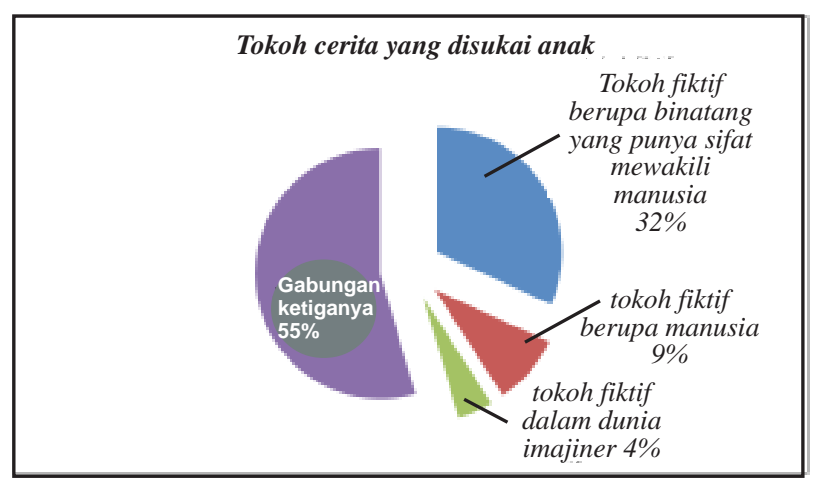

Diagram 7. Tokoh cerita yang disukai anak

Salah satu butir pertanyaan dalam kuesioner adalah apakah materi cerita perlu mengacu pada tema tertentu? Hasil pengolahan data responden menunjukkan bahwa sebanyak $79 \%$ responden menyatakan materi cerita perlu mengacu pada tema tertentu agar guru lebih fokus dalam menyampaikan cerita sehingga dapat mencapai tujuan cerita. Hal ini menunjukkan bahwa sebagian besar responden memahami salah satu prosedur pelaksanaan kegiatan bercerita adalah menetapkan tujuan dan tema cerita. Selain itu, semua responden (100\%) menyatakan bahwa pesan atau amanat cerita perlu disampaikan secara jelas atau eksplisit di akhir cerita. Hal ini karena tujuan kegiatan bercerita untuk anak usia dini adalah menanamkan pesan-pesan atau nilainilai sosial, moral, dan agama yang terkandung dalam sebuah cerita.

Nilai-nilai karakter yang dituangkan dalam cerita tersebut diharapkan responden dikemas menggunakan bahasa Indonesia, bahasa yang sederhana, jelas, dan mudah dipahami oleh anak usia dini.

Durasi media audio yang sesuai untuk menyampaikan cerita bagi anak usia dini menurut penelitian ini berkisar antara 8 sampai 10 menit (43\%). Diagram 8 menunjukkan durasi media audio cerita pendidikan karakter untuk anak usia dini. Temuan ini sesuai dengan kesimpulan para ahli bahwa waktu bercerita untuk anak usia 4-8 tahun adalah 10-15 menit. Kesimpulan tersebut didasarkan pada pertimbangan bahwa daya pikir, kemampuan berbahasa, dan daya tangkap anak masih terbatas (Hasanah, 2014).

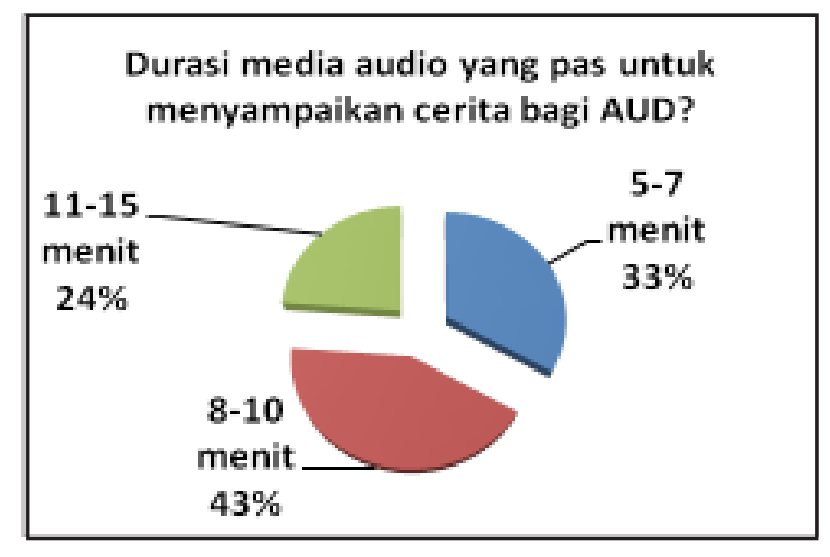

Diagram 8. Persentase durasi media audio cerita pendidikan karakter untuk AUD

Semua responden (100\%) menyatakan bahwa media audio cerita pendidikan karakter perlu dilengkapi dengan panduan pemanfaatan. Panduan pemanfaatan bertujuan untuk memberi informasi kepada guru bagaimana cara memanfaatkan media audio cerita pendidikan karakter dalam kegiatan pembelajaran. Panduan pemanfaatan berisi identitas program, petunjuk umum, petunjuk khusus (sebelum, selama, dan setelah memanfaatkan program), 
sinopsis cerita, evaluasi program, dan daftar pustaka (Suparti dan Susanti, 2016).

Menurut sebagian besar responden (75\%), kemasan (casing) CD media audio sebaiknya dilengkapi dengan sampul program yang menampilkan identitas program dengan tulisan dan gambar yang menarik, mengandung sinopsis cerita, serta petunjuk pemanfaatan yang disatukan dengan CD program. Hal ini dapat dilihat pada Diagram 9 mengenai persentase casing media audio yang diinginkan responden. Sementara itu, semua responden juga berpandangan bahwa cerita pendidikan karakter yang disampaikan melalui media audio harus benar-benar menampilkan suara pencerita dan tokoh audio yang menarik, musik, dan efek suara juga ditampilkan untuk mendukung suasana dan menambah imajinasi anak. Musik adalah unsur hiburan yang memiliki kekuatan menentukan mood, menunjukkan suasana atau atmosfir, menjadi tema, melatarbelakangi sebuah dialog, sebagai penanda untuk pembukaan dan penutupan, serta dapat memberi penekanan pada kalimat atau frase tertentu (Susanti, 2015). Efek suara yang digunakan dalam produksi media audio pendidikan, khususnya yang dikembangkan oleh BPMRPK, memiliki fungsi untuk menentukan tempat, memproyeksikan tindakan nyata, dan untuk menentukan suasana/atmosfir (Susanti, 2015).

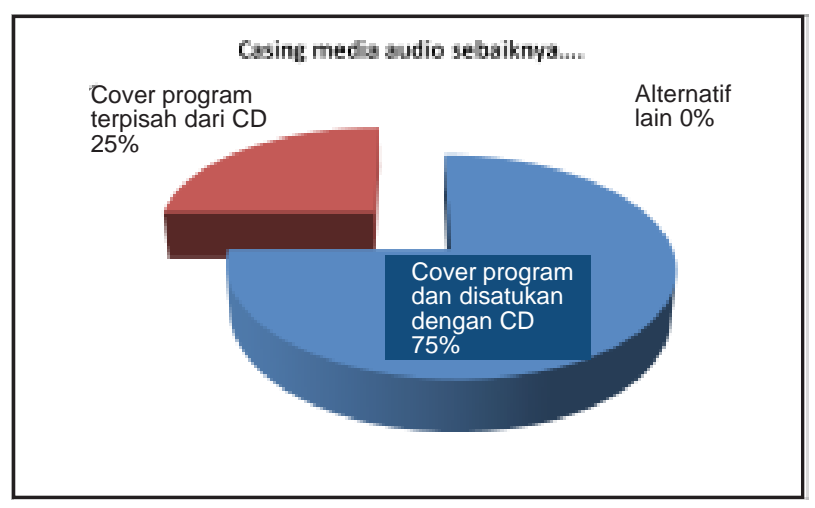

Diagram 9. Persentase casing media audio yang diinginkan responden

Nilai-nilai pendidikan karakter yang bisa disampaikan melalui media audio bercerita. Nilai-nilai pendidikan karakter yang perlu disajikan dalam kegiatan bercerita melalui media audio menurut responden adalah ke-16 nilai pendidikan karakter. Responden menganggap bahwa nilai percaya adanya Tuhan melalui ciptaan-Nya menduduki peringkat teratas, diikuti dengan nilai menghargai diri sendiri, orang lain, dan lingkungan sekitar sebagai rasa syukur kepada Tuhan, perilaku dapat menyesuaikan diri, perilaku jujur, rendah hati, dan santun juga menjadi nilai pendidikan karakter yang mendapat prioritas untuk dikemas dalam cerita. Dengan demikian, hasil penelitian sudah menjawab tujuan penelitian berikutnya yaitu nilai-nilai karakter apa saja yang dapat diungkap dalam media audio cerita pendidikan karakter.

\section{SIMPULAN DAN SARAN Simpulan}

Berdasarkan hasil penelitian yang disampaikan sebelumnya, simpulan penelitian adalah sebagai berikut.

Pertama, secara umum, kemampuan guru dalam bercerita cukup bagus sekalipun sarana dan prasarananya masih terbatas.

Kedua, guru PAUD/TK sangat membutuhkan media audio cerita pendidikan karakter untuk menanamkan nilai-nilai mulia kepada anak usia dini. Simpulan ini diambil berdasarkan temuan penelitian yang menunjukkan bahwa metode bercerita belum menjadi prioritas pertama dalam kegiatan pembelajaran yang dilakukan oleh guru TK di Kabupaten Bantul, Gunungkidul, dan Sleman Provinsi DIY karena keterbatasan materi/media yang dimiliki sekolah. Teknik bercerita yang paling banyak dipakai oleh guru TK di tiga kabupaten tersebut adalah bercerita secara langsung/lisan tanpa menggunakan media bantu, seperti buku cerita, boneka jari, ilustrasi gambar, media audio, dan media audio visual. Guru TK yang menggunakan media audio untuk bercerita masih sedikit, sebagian besar menggunakan media audio untuk kegiatan bernyanyi dan menari.

Ketiga, media audio cerita pendidikan karakter yang dibutuhkan guru PAUD/TK adalah yang mendidik sekaligus menghibur. Unsur hiburan yang dimaksud adalah penggunaan musik, efek suara, dan suara tokoh audio. Pencerita juga harus menarik 
dan mampu merangsang imajinasi anak usia dini. Jenis cerita yang paling disukai anak usia dini adalah fabel atau cerita binatang, tumbuhan, atau benda mati yang memiliki kebiasaan, adat istiadat, sifat, dan sikap seperti manusia. Bahasa yang dikehendaki adalah bahasa Indonesia, jelas, sederhana, dan mudah dipahami oleh anak usia dini. Durasi media audio cerita pendidikan karakter juga harus menyesuaikan dengan daya tahan anak untuk mendengarkan, yaitu berkisar antara 8-10 menit. Penggunaan media audio cerita pendidikan karakter sebagai sisipan di salah satu kegiatan pembelajaran mengharuskan guru TK mengetahui cara penggunaannya. Oleh sebab itu, diperlukan adanya panduan pemanfaatan di setiap judul program yang menjelaskan tentang petunjuk umum, petunjuk khusus (sebelum, selama, dan sesudah memanfaatkan program), sinopsis cerita, dan evaluasi. Kemasan yang menarik dan informatif juga dibutuhkan dalam pengemasan media audio cerita pendidikan karakter.

Keempat, Nilai-nilai pendidikan karakter yang dapat disampaikan melalui media audio adalah ke16 nilai pendidikan karakter, yaitu antara lain: percaya kepada Tuhan melalui ciptaan-Nya, jujur, rendah hati, suka menolong, dan sebagainya.
Hasil penelitian berguna untuk menjadi landasan bahwa guru atau pendidik TK di Kabupaten Bantul, Sleman, dan Gunungkidul Provinsi DIY membutuhkan media audio cerita pendidikan karakter yang menarik dan dapat dipertanggungjawabkan kebenarannya.

\section{Saran}

Hasil penelitian ini memberikan rekomendasi kepada BPMRPK Kemendikbud untuk mengembangkan model media audio cerita pendidikan karakter untuk menunjang pembelajaran guru PAUD/TK. Pendidikan karakter yang diharapkan muncul dalam cerita pendidikan karakter ini adalah semua nilai yang tercantum di dalam Kurikulum 2013, yaitu mencakup kompetensi inti sikap spiritual dan sikap sosial. Nilai-nilai karakter yang perlu diprioritaskan untuk dikemas dalam cerita pendidikan karakter adalah percaya adanya Tuhan melalui ciptaan-Nya, menghargai diri sendiri, orang lain, dan lingkungan sekitar sebagai rasa syukur kepada Tuhan, perilaku yang mencerminkan taat kepada aturan, perilaku yang mencerminkan kemampuan untuk menyesuaikan diri, jujur, rendah hati, dan santun.

\section{PUSTAKA ACUAN}

Cholimah, Nur. 2016. Membangun Keaksaraan pada Anak Usia Dini Melalui Model Audio Aku Baca dalam Cerita. Yogyakarta: disampaikan pada Kegiatan Validasi Rancangan Model untuk PAUD tanggal 18 Mei 2016 di LPP Convention Center, Demangan.

Daryanto. 2016. Media Pembelajaran. Yogyakarta: Gava Media.

Davis, Angliah L. 2013. Using Instructional Design Principles to Develop Effective Information Literacy Instruction. The ADDIE Model. http://crln.acrl.org/content/74/4/205.short. Diakses 20 Juni 2016.

Hackbarth, Steven.1998. The Educational Technology Handbook: A Comprehensive Guide: Process and Products for Learning. New Jersey: Educational Technology Publications.

Haryati, Isti. 2011. Fabel dalam Pengajaran Literatur dan Pendidikan Karakter. Prosiding Seminar Nasional Pengajaran Bahasa Asing dan Pendidikan Karakter pada tanggal 10 November 2011 oleh Jurusan Pendidikan Bahasa Jerman Fakultas Bahasa dan Seni Universitas Negeri Yogyakarta.

Haryono. 2006. Pengembangan Media Audio. Disampaikan pada Pelatihan Penulisan Naskah Program Audio Pendidikan BPMR Yogyakarta 17-21 Juli 2006.

Hasanah, L., Dharmayana, I. W., \& Delrefi, D. 2014. Meningkatkan Kemandirian Belajar Anak Dengan Menggunakan Metode Bercerita Berbantuan Media Film/VCD Pada Kelompok B1 TK Gow Curup. Doctoral dissertation, Universitas Bengkulu. 
Suparti dan Mariana Susanti: Analisis Kebutuhan Medua Audio Cerita Pendidikan Karakter untuk Usia Dini

Husaeni, Adian. 2010. Pendidikan Islam Membentuk Manusia Berkarakter dan Beradab. http://pf.uad.ac.id/wp-content/ files/pendidikan-islam-membangun-manusia-berkarakter-dan-beradab.pdf. Diakses 22 Juni 2016.

Jaliusril, dkk. 2012. Pengembangan Media Audio-Visual Pembelajaran Lari Jarak Pendek untuk Siswa SMP. Jurnal Teknodik Pedagogi. Vol.2 No.1 Maret 2012.

KBBI. 2008. Kamus Besar Bahasa Indonesia (KBBI) versi online. http://kbbi.web.id/karakter. Diakses 22 Juni 2016.

Kementerian Pendidikan dan Kebudayaan. 2015. Pedoman Penanaman Sikap Pendidikan Anak Usia Dini. Jakarta: Direktorat Jenderal Pendidikan Anak Usia Dini.

McCawley, Paul F. 2009. Methods for Conducting an Educational Needs Assessment. https://www.cals.uidaho.edu/edcomm/ pdf/BUL/BUL0870.pdf. Diakses 20 Juni 2016.

Megawangi, Ratna. tt. Pengembangan Program Pendidikan Karakter di Sekolah: Pengalaman Sekolah Karakter. http:// pustaka.ut.ac.id/pdfartikel/TIG101.pdf. Diakses 22 Juni 2016.

Muhtadi, Ali. 2010. Implementasi Pendidikan Karakter dalam Kurikulum Sekolah. http://staff.uny.ac.id/sites/default/files/ tmp/Implementasi\%20Pendidikan\%20karakter\%20dalam\%20kurikulum\%20di\%20sekolah.pdf. Diakses 22 Juni 2016.

Nuryanto, Sidik. 2015. Implementasi Pendidikan Karakter dengan Dongeng pada Anak Usia Dini. Ponorogo: Prosiding Seminar Nasional Pendidikan "Inovasi Pembelajaran untuk Pendidikan Berkemajuan tanggal 7 November 2015 di Universitas Muhammadiyah Ponorogo.

Office of Migrant Education. 2001. Comprehensive Needs Assessment. https://www2.ed.gov/admins/lead/account/ compneedsassessment.pdf. Diakses 20 Juni 2016.

Purwanti. 2014. Upaya Meningkatkan Tanggungjawab Anak dengan Metode Bercerita Bermedia Audio Visual pada Kelompok A di RA Sholichah Gempolan Kulon Trirenggo Bantul Tahun Ajaran 2013/2014. Skripsi. Program Studi Pendidikan Guru Madrasah Ibtidaiyah. Fakultas IImu Tarbiyah dan Keguruan. Universitas Islam Negeri Sunan Kalijaga.

Rahmawati, Zulfrida. 2012. Pengenalan Budaya Melalui Bercerita untuk Anak Usia Dini. Jurnal UNY, Jurnal Pendidikan Anak, Volume 1, Edisi 1, Juni 2012.

Riduwan dan Akdon. 2013. Rumus dan Data dalam Aplikasi Statistika untuk Penelitian: Administrasi Pendidikan-BisnisPemerintahan-Sosial-Kebijakan-Ekonomi-Hukum-Manajemen-Kesehatan. Bandung: Alfabeta.

Rita. 2014. Meningkatkan Kemandirian melalui Cerita Video pada Anak Kelompok B PAUD Al-Mujadid Kota Lubuklinggau. Skripsi. Program Sarjana Kependidikan bagi Guru dalam Jabatan. Fakultas Keguruan dan IImu Pendidikan. Universitas Bengkulu. Diakses dari http://repository.unib.ac.id/8704/1/I,II,III,II-14-rit.FK.pdf pada tanggal 21 Juni 2016.

Shufiyati, Efta. 2013. Keefektifan Metode Penanaman Moral Bermuatan Pendidikan Karakter bagi Siswa Pendidikan Anak Usia Dini di Kota Semarang. Skripsi, Jurusan Politik dan Kewarganegaraan. Fakultas Ilmu Sosial. Universitas Negeri Semarang. Diakses dari http://lib.unnes.ac.id/19972/1/3301409027.pdf pada tanggal 21 Juni 2016.

Smaldino, Sharon E, dkk. 2008. Instructional Technology and Media for Learning. Ohio: Pearson Merrill Prentice Hall. Susanti, Mariana. 2015. Pendidikan dan Hiburan dalam Drama Radio Pendidikan (Analisis Isi Naskah Drama Radio "Generasi Edu"). Makassar: Jurnal Pekommas Vol. 18 No. 1 Hal. 15-26 , April 2015 ISSN: 1411-0385.

Waldopo. 2008. Pemanfaatan Media Audio dan Radio untuk Pembelajaran: Modul 9. Jakarta: Pustekkom Depdiknas. Watkins, Ryan; Meiers, Maurya; Visser, Yusra. 2012. A Guide to Assessing Needs. Essential Tools for Collecting Information, Making Decisions, and Achieving Development Results. Washington: The World Bank.

\section{UCAPAN TERIMAKASIH}

Penulis menyadari bahwa artikel ini dapat diselesaikan atas dukungan dan bantuan dari berbagai pihak. Oleh karena itu, penulis mengucapkan terima kasih kepada semua pihak yang telah memberikan kontribusi dalam penyelesaian artikel ini. Secara khusus, ucapan terima kasih disampaikan kepada Dr. Purwanto selaku penyunting naskah dan Drs. Bambang Warsita, M.Pd sebagai dewan redaksi Jurnal Teknodik atas koreksi dan masukan yang diberikan.

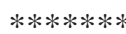

